\title{
Non-Vascular Plant
}

National Cancer Institute

\section{Source}

National Cancer Institute. Non-Vascular Plant. NCI Thesaurus. Code C14340.

A plant that does not have vascular tubes/tissues to transport food and water. It belongs

to the division Bryophyta, which includes liverwort, and moss. 